\title{
The rise and fall of infectious disease in a warmer world
}

\section{[version 1; peer review: 2 approved]}

\author{
Kevin D. Lafferty ${ }^{1}$, Erin A. Mordecai² \\ ${ }^{1}$ Western Ecological Research Center, U.S. Geological Survey at Marine Science Institute, University of California, Santa Barbara, CA, \\ 93106, USA \\ 2Department of Biology, Stanford University, Stanford, CA, 94305, USA
}

\begin{tabular}{l} 
V1 First published: 19 Aug 2016, 5(F1000 Faculty Rev):2040 \\
https://doi.org/10.12688/f1000research.8766.1 \\
Latest published: 19 Aug 2016, 5(F1000 Faculty Rev):2040 \\
https://doi.org/10.12688/f1000research.8766.1 \\
\hline
\end{tabular}

\begin{abstract}
Now-outdated estimates proposed that climate change should have increased the number of people at risk of malaria, yet malaria and several other infectious diseases have declined. Although some diseases have increased as the climate has warmed, evidence for widespread climate-driven disease expansion has not materialized, despite increased research attention. Biological responses to warming depend on the non-linear relationships between physiological performance and temperature, called the thermal response curve. This leads performance to rise and fall with temperature. Under climate change, host species and their associated parasites face extinction if they cannot either thermoregulate or adapt by shifting phenology or geographic range. Climate change might also affect disease transmission through increases or decreases in host susceptibility and infective stage (and vector) production, longevity, and pathology. Many other factors drive disease transmission, especially economics, and some change in time along with temperature, making it hard to distinguish whether temperature drives disease or just correlates with disease drivers. Although it is difficult to predict how climate change will affect infectious disease, an ecological approach can help meet the challenge.
\end{abstract}

Keywords

infectious disease, climate change, ecology

\section{Open Peer Review \\ Approval Status \\ 1 \\ 2 \\ version 1 \\ 19 Aug 2016 \\ Faculty Reviews are review articles written by the prestigious Members of Faculty Opinions. The articles are commissioned and peer reviewed before publication to ensure that the final, published version is comprehensive and accessible. The reviewers who approved the final version are listed with their names and affiliations.}

1. Camille Parmesan, Plymouth University,

Plymouth, UK

2. Maria Diuk-Wasser, Columbia University,

New York, USA

Any comments on the article can be found at the end of the article. 
Corresponding author: Kevin D. Lafferty (lafferty@lifesci.ucsb.edu)

Competing interests: The authors declare that they have no competing interests.

Grant information: Any use of trade, product, or firm names in this publication is for descriptive purposes only and does not imply endorsement by the U.S. government. EAM was funded by the National Science Foundation (DEB-1518681 and DEB-1640780) and the Stanford University Center for Innovation in Global Health and Woods Institute for the Environment.

The funders had no role in study design, data collection and analysis, decision to publish, or preparation of the manuscript.

Copyright: @ 2016 Lafferty KD and Mordecai EA. This is an open access article distributed under the terms of the Creative Commons Attribution License, which permits unrestricted use, distribution, and reproduction in any medium, provided the original work is properly cited.

How to cite this article: Lafferty KD and Mordecai EA. The rise and fall of infectious disease in a warmer world [version 1; peer review: 2 approved] F1000Research 2016, 5(F1000 Faculty Rev):2040 https://doi.org/10.12688/f1000research.8766.1

First published: 19 Aug 2016, 5(F1000 Faculty Rev):2040 https://doi.org/10.12688/f1000research.8766.1 


\section{Introduction}

It is almost 2020, the year in which early efforts predicted that climate change would have increased the number of people at risk of malaria by $60 \%{ }^{1}$. As with many parasitic diseases, the malaria parasite and its mosquito vectors are most prevalent in the tropics and have annual peaks during or after warm seasons. Early climate models predicted that warming would expand parasite and mosquito vector ranges beyond the tropics. Furthermore, temperature change can stress hosts, and stress might make them more susceptible to infection or death. Finally, some diseases have emerged or increased ${ }^{2}$ just as global greenhouse effects ${ }^{3}$, urban heat islands ${ }^{4}$, and devegetation ${ }^{5}$ have increased temperatures over the last century, suggesting that this warmer world will be a sicker world ${ }^{6}$. Concern for a sicker world led to increased research on climate change and infectious disease ${ }^{7}$, and public opinion and funders took notice ${ }^{8}$. As a result, we now better understand the complex linkages between climate and disease transmission.

Although the globe has warmed, many human infectious diseases (particularly those responsible for the most human suffering) have declined since $1999^{\circ}$, with some notable exceptions (for example, West Nile, Ebola, dengue, chikungunya, and Zika). For example, although warming has expanded highland malaria transmission in some places, transmission did not increase into western Europe and the United States (Box 1) ${ }^{10}$. Instead, after rising with population growth, mortalities declined by $40 \%$ in Africa between 2000 and 2015 , and this was largely due to insecticide-treated bed nets and other interventions ${ }^{11}$. The decline in malaria in a warming world shows how economic growth and interventions can mask climate effects. By contrast, other pathogens have expanded in recent years, particularly arboviruses such as West Nile, dengue, chikungunya,

\section{Box 1. Malaria and climate}

The world's most important parasitic disease is malaria Climate affects the malaria parasite and the mosquitoes that vector it. However, there is a distinction between climate suitability for transmission and realized transmission because even when climate is suitable for malaria transmission, many additional factors interrupt transmission ${ }^{14}$. In fact, economic development has trumped climate in determining the global malaria distribution, reducing malaria transmission in developed nations even as temperatures have become more permissive ${ }^{15}$ Meanwhile, malaria resurged in Greece after health services had been cut following the 2008 recession (though some have blamed a warming climate as well) ${ }^{16}$. In developing nations with limited vector control and healthcare infrastructure, climate can still hold sway. In particular, malaria has increased at high-altitudes in East Africa because of warming ${ }^{10}$. Across a broader temperature range, climate impacts on malaria transmission are more subtle and include expanding the transmission season ${ }^{17}$. At continental scales, some models project expansions in climate suitability for malaria ${ }^{18}$, whereas other models, based on different curves, predict poleward (and altitudinal) shifts ${ }^{14,19}$ or decreases ${ }^{20}$. These different predictions stem from different model assumptions. In particular, non-linearities in the performance curves for malaria and mosquitoes have suggested that optimal temperatures for transmission are much lower than previously thought ${ }^{21,22}$ and that in future warming scenarios much of Africa will be too warm for efficient transmission ${ }^{23}$ and Zika, pandemic influenza viruses, Ebola virus, and coronaviruses that cause severe acute respiratory syndrome (SARS) and Middle Eastern respiratory syndrome (MERS). The resurgence and spread of these diseases are thought to be linked to global change (for example, urbanization, land use change, climate change, and global travel), but direct links to climate change have not been established ${ }^{12}$. In sum, many diseases are changing - some decreasing dramatically and others expanding and emerging-but the evidence linking these shifts to climate change is limited.

\section{Rise and fall}

Biological responses to warming, including infectious diseases, depend on the non-linear relationships between performance and temperature. Temperature increases enzyme function ${ }^{24}$, membrane permeability ${ }^{25}$, and respiration rate ${ }^{26}$ while decreasing molecular stability. These opposing temperature effects result in hump-shaped thermal reaction norms (or performance curves) that rise from a minimal temperature limit to a peak at the optimal temperature, followed by a sharp fall to a critical maximum temperature limit ${ }^{27}$ (Figure 1). When gene flow and acclimation are limited ${ }^{28}$, laboratory organisms evolve to optimize performance by specializing on a fixed laboratory temperature ${ }^{29}$, resulting in high and narrow performance curves. However, because field temperatures vary (daily, seasonally, annually, and decadally), especially with latitude, species either evolve low and broad thermal performance curves ${ }^{30}$ or regulate toward an optimal temperature through endothermy, behavior, phenology, or migration ${ }^{31}$. Such adaptations have established thermal niches that have bounded species distributions for millennia. But what happens if global temperatures increase faster than species' thermal niches can adapt?

How any species, parasite or free-living, responds to increased global temperature depends on their current thermal response curve and their ability to thermoregulate, adapt (including shifts in phenology), and shift geographic ranges ${ }^{32}$. For instance, species from high latitudes can tolerate considerable warming because

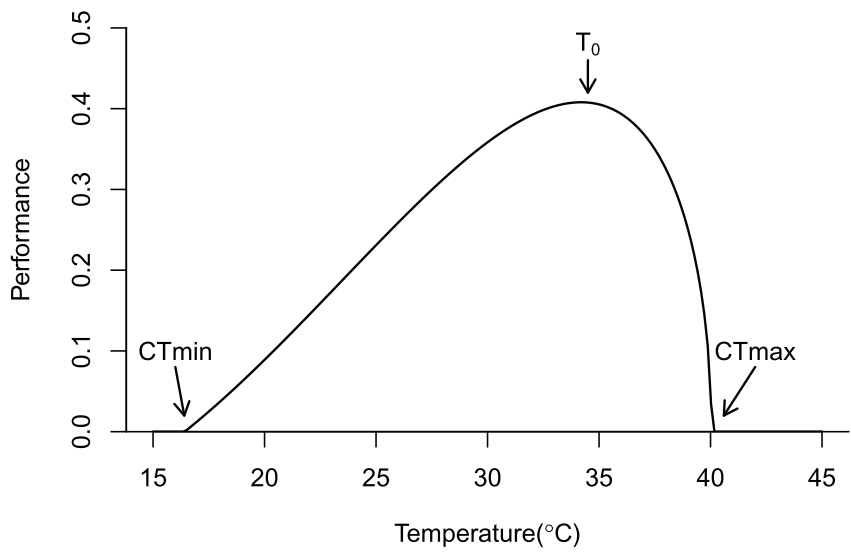

Figure 1. A thermal performance curve for a hypothetical ectotherm. All species, whether free-living or parasitic, rise and fall with temperature. Performance rises slowly from the critical thermal minimum (CTmin) to a thermal optimum (To), declining sharply to the critical thermal maximum (CTmax). 
they are adapted to variable temperatures ${ }^{33}$. In contrast, most tropical species have narrow thermal response curves and limited thermoregulation ${ }^{33}$. If such species are mobile, their geographic ranges should shift to higher latitudes and altitudes. In contrast, sedentary or island species might either adapt to warmer temperatures or go extinct. As parasite and host ranges shift, generalist parasites with broad host ranges should persist. By contrast, specialist parasites should be more sensitive because climate change could disrupt parasite transmission and reduce parasite burdens while also disrupting host populations. Host pathology could increase if infectious agents adapt faster to higher temperatures. This could be the case for long-lived, sedentary tropical hosts (like trees or corals) that have limited capacity to tolerate, adapt to, or move in response to temperature increases ${ }^{6}$. Depending on the system, parasite transmission, pathology, and geographic range could decline, increase, or stay the same, making general predictions challenging ${ }^{34}$.

Climate change might also affect disease transmission through host susceptibility, which depends, in part, on investment in defense. It is common to assume that warming will decrease immune function because cellular and humoral immune defenses are expensive to maintain ${ }^{35}$ and can collapse under thermal stress. For instance, black abalone become more susceptible to rickettsia infection under variable temperatures and infected individuals die faster as mean temperature rises ${ }^{36}$. On the other hand, warmer temperatures can increase immune response in fishes and amphibians ${ }^{37}$, oak resistance to sudden oak death ${ }^{38}$, and the immune response to cold virus in humans ${ }^{39}$. Given these diverse responses, the immune response, like other performance measures, should follow a humpshaped temperature response curve with decreased function at lower or higher than optimal temperatures, though too few data exist to generalize ${ }^{37}$. Another way susceptibility can respond to climate change is if shifts in pathogen distributions expose naïve host populations to new diseases ${ }^{40}$; a key example is occurring in the Ethiopian highlands, where recent malaria expansions have caused increased disease in previously unexposed populations ${ }^{41,42}$. Overall, climate change could affect host susceptibility, but the effect probably varies with temperature and other factors.

Temperature also affects parasite transmission through infective stage (and vector) production and longevity. For example, an influenza virion's viability decreases with temperature so that flu transmission is lower during mild El Niño winters than in normal cold winters in California ${ }^{43}$. In contrast, transmission stage production in ectothermic hosts should increase with temperature up to a thermal optimum; for example, nematode parasites have increased in warming Arctic areas where larval development rates have increased $^{44,45}$. Increases in parasite and host death rates can counteract this temperature effect on parasite production. For instance, snails shed more amphibian-seeking trematode larvae under warmer temperatures ${ }^{46}$, and one might expect that parasite intensity would increase. However, trematode intensity is halved in a $3^{\circ} \mathrm{C}$ warming experiment because of an increase in parasite and host death rate ${ }^{47}$. This dual effect of production and death on transmission helps explain why some trematode infections increase with warmer water $^{48}$, whereas other species do better at cold temperatures ${ }^{49}$. Likewise, although field observations initially suggested that swallow parasites would increase with global warming, experimentally heating nests above ambient temperature killed parasites, leading to a sharp decline in parasitism ${ }^{50}$. Similarly, increasing temperature hastens Plasmodium development but, above a certain temperature, transmission declines because of increased mosquito death, leading to hump-shaped temperature-transmission curves ${ }^{51}$.

The shape and range of a thermal response curve (Figure 1) determine where temperature suitability for an infectious disease will increase or decrease with climate change, with differences in model curves altering model predictions (Box 1). Potential poleward shifts in suitability for tropical diseases predicted from the thermal performance curve can cause alarm in countries at high latitudes ${ }^{52}$. Fortunately, many high-latitude countries are able to mitigate such risks because of higher economic development and healthcare infrastructure ${ }^{53}$.

Host pathology should often follow the parasite thermal performance curve ${ }^{54}$. For instance, the fungal pathogens responsible for amphibian declines have a cool optimal temperature ${ }^{55}$ and are expected to cause fewer problems as climate warms ${ }^{56}$. However, host death rates tend to increase with temperature, as seen for infected corals ${ }^{57,58}$, sea stars ${ }^{59,60}$, and abalone ${ }^{61,62}$ that have suffered catastrophic mass mortalities. Because temperature-induced host death kills parasites, it can, in the long term, drive a host-specialist parasite to extinction ${ }^{36,63}$. For this reason, the most pathogenic parasites have a hard time persisting without a tolerant reservoir host.

\section{Other drivers}

Many factors drive disease transmission, including some that have changed in time along with climate. A key factor is host density (including vectors and reservoir hosts), which should increase the force of infection ${ }^{64}$. For instance, although marine disease reports have increased over time ${ }^{65}$, and some, like coral diseases, might be due to increased temperature, most disease reports parallel changes in host abundance (due to either increased disease transmission or increased detection). In particular, the one group for which disease reports declined over time was commercially valuable fishes, which have suffered global stock collapses ${ }^{66}$. For human, crop, and livestock diseases, economic development is another key driver ${ }^{67,68}$. Most notably, it is clear from historical data that malaria does not occupy its full ecological niche, due to its elimination from wealthier nations ${ }^{69}$, leading to a decline in malaria's distribution as the earth has warmed ${ }^{15,34}$. Economic growth drives health interventions such as vector control, increased sanitation, deforestation, and shifts to urban living with limited wildlife contact, all of which can reduce disease emergence and spread $^{70}$. However, economic growth also drives global travel and trade, which can unintentionally spread pathogens. Contact networks for directly transmitted diseases are now global due to air travel and trade routes that continue to introduce invasive species, which, on average, bring with them two parasitic species per host species ${ }^{42}$. These novel parasites meet naïve hosts with unpredictable outcomes. Because host density and economics change over time, it can be hard to separate climate change effects from other changes. Current examples are emerging and resurging dengue, chikungunya, and Zika viruses. These viruses benefitted 
from vector expansion and invasion, lapsed vector control, global tire trade, global human movement, urbanization and unplanned development, deforestation, high human densities, and poverty ${ }^{71}$. Despite these drivers, climate change captures the headlines, such as "In Zika Epidemic, a Warning on Climate Change" "72.

Many emerging and resurging diseases in wildlife (for example, chytridiomycosis, and white nose syndrome) and in humans (for example, dengue, Zika, chikungunya, and diarrheal diseases) are increasing in prevalence and geographic range over time as climate changes, constituting the main evidence to link a warmer world with a sicker world ${ }^{7,73}$. However, other drivers can correlate with temperature changes, making it difficult to separate a temperature effect from a spurious correlation. In particular, disease events during warm years are not sufficient evidence for a climate change effect because diseases emerge each year for various reasons. For instance, seven out of nine historical yellow fever epidemics occurred in different cities during the 1878-79 El Niño ${ }^{74}$, but this strong El Niño effect disappears after considering longer time series $^{34}$. Because the recent Brazilian Zika epidemic occurred during an El Niño, similar claims have been made for Zika virus ${ }^{75}$ even though Zika had previously spread throughout the South Pacific without fanfare ${ }^{76}$. Although increases in new human diseases and new locations for old diseases are alarming, some may be due to species introductions or increased surveillance and reporting but have no clear link to climate ${ }^{2}$. Sometimes a causal link between temperature and disease is not due to thermal physiology or climate change. In addition to direct physiological effects, temperature can indirectly affect disease dynamics. A temperature association can occur if warming drives changes in abundance or movement that affect transmission. For example, warming increases disease in monarch butterflies because a milder climate removes the need to migrate, which benefits protozoan parasites otherwise lost when infected hosts die during migration ${ }^{77}$. In other cases, a temperature effect is not a climate change effect. For example, deforestation creates warmer microclimates, which, in turn, can increase local malaria transmission ${ }^{78}$. Regardless, the difficulty in establishing a link between climate change and disease does not mean no link exists, just that observed links have alternative explanations that might be more or less likely. For these reasons, temperature-disease correlations best indicate a climate change effect if they persist after removing the temporal trend and have experimental support.

When climate does associate with an increase in a disease in a particular location, it is important not to overgeneralize. Sometimes effects vary among hosts, such as the observation that parasites increased in some but not all European bird species over 5- to 15-year time intervals, with a positive association between changes in temperature and changes in parasitism ${ }^{79}$. Results can also be inconsistent among similar parasite species. For instance, a 30-year study found that one rabbit nematode species increased along with increases in temperatures but that a second did not change $^{80}$. Similarly, while temperature increased at Finnish fish farms, two pathogens increased and two declined ${ }^{81}$. Finally, an increase in one location might be paired with a decrease at another location $^{23}$. Although general explanations are attractive, we should expect winners and losers as climate changes.

\section{Conclusion}

Although it is difficult to test how climate affects infectious disease burdens in humans, livestock, and wildlife, the implications for human wellbeing make it imperative that we meet the challenge. Fortunately, climatologists are making headway defining climate change, and their efforts could lead to new insights into potential disease drivers like disproportionate increases in nighttime or winter temperatures, reduced temperature variation, increased extreme event intensity and frequency, and changes to precipitation. Armed with better climate information, ecologists can use experiments, mathematical and statistical modeling, and observational work to understand and predict how infectious disease responds to climate change ${ }^{82}$. Basic information on thermal physiology is lacking, but various efforts are underway to better describe infectious agent and vector thermal niches by describing their thermal performance curves, testing for local adaptation, and measuring thermoregulation. Once we understand thermal physiology better, a greater appreciation for the economic and environmental factors driving infectious diseases will make it easier to evaluate climate change effects in relation to parallel changes such as land conversion, urbanization, species assemblages, host movement, and demography ${ }^{83}$. At that point, we can predict which diseases are most likely to emerge where, so that public health agencies can best direct limited disease control resources ${ }^{84}$, rather than wondering whether a warmer world will be a sicker world.

\section{Competing interests}

The authors declare that they have no competing interests.

\section{Grant information}

Any use of trade, product, or firm names in this publication is for descriptive purposes only and does not imply endorsement by the U.S. government. EAM was funded by the National Science Foundation (DEB-1518681 and DEB-1640780) and the Stanford University Center for Innovation in Global Health and Woods Institute for the Environment.

The funders had no role in study design, data collection and analysis, decision to publish, or preparation of the manuscript.

\section{Acknowledgements}

The authors thank Maria Diuk-Wasser, Camille Parmesan, Clark Marino, Sara Weinstein, and Isabel Jones for comments on an earlier draft. 
1. Martens $\mathrm{P}$, Kovats RS, Nijhof $\mathrm{S}$, et al:: Climate change and future populations at risk of malaria. Glob Environ Change. 1999; 9(Supplement 1): S89-S107. Publisher Full Text

2. $\mathrm{F}$ Jones KE, Patel NG, Levy MA, et al:: Global trends in emerging infectious diseases. Nature. 2008; 451(7181): 990-3. PubMed Abstract | Publisher Full Text | F1000 Recommendation

3. Charlson RJ, Schwartz SE, Hales JM, et al:: Climate forcing by anthropogenic aerosols. Science. 1992; 255(5043): 423-30. PubMed Abstract | Publisher Full Text

4. Grimm NB, Foster D, Groffman P, et al:: The changing landscape: Ecosystem responses to urbanization and pollution across climatic and societal gradients. Front Ecol Environ. 2008; 6(5): 264-72. Publisher Full Text

5. Nelson KC, Palmer MA: Stream Temperature Surges under Urbanization and Climate Change: Data, Models, and Responses. J Am Water Resources Assoc. 2007; 43(2): 440-52.
Publisher Full Text

6. Harvell $C D$, Mitchell CE, Ward JR, et al:: Climate warming and disease risks for terrestrial and marine biota. Science. 2002; 296(5576): 2158-62. PubMed Abstract | Publisher Full Text

7. F Altizer S, Ostfeld RS, Johnson PT, et al.: Climate change and infectious diseases: from evidence to a predictive framework. Science. 2013; 341(6145): 514-9.

PubMed Abstract | Publisher Full Text | F1000 Recommendation

8. Huntingford C, Hemming D, Gash JH, et al:: Impact of climate change on health: what is required of climate modellers? Trans R Soc Trop Med Hyg. 2007; 101(2): 97-103.

PubMed Abstract | Publisher Full Text

9. Vos T, Flaxman AD, Naghavi M, et al.: Years lived with disability (YLDs) for 1160 sequelae of 289 diseases and injuries 1990-2010: a systematic analysis for the Global Burden of Disease Study 2010. Lancet. 2012; 380(9859): 2163-96. PubMed Abstract | Publisher Full Text

10. F Siraj AS, Santos-Vega M, Bouma MJ, et al:: Altitudinal changes in malaria incidence in highlands of Ethiopia and Colombia. Science. 2014; 343(6175): $1154-8$

PubMed Abstract | Publisher Full Text | F1000 Recommendation

11. F Bhatt S, Weiss DJ, Cameron E, et al.: The effect of malaria control on Plasmodium falciparum in Africa between 2000 and 2015. Nature. 2015; 526(7572): 207-11.

PubMed Abstract | Publisher Full Text | Free Full Text | F1000 Recommendation

12. Gould EA, Higgs S: Impact of climate change and other factors on emerging arbovirus diseases. Trans R Soc Trop Med Hyg. 2009; 103(2): 109-21. PubMed Abstract | Publisher Full Text | Free Full Text

13. Sachs J, Malaney P: The economic and social burden of malaria. Nature. 2002 415(6872): 680-5.

PubMed Abstract | Publisher Full Text

14. Rogers DJ, Randolph SE: The global spread of malaria in a future, warmer world. Science. 2000; 289(5485): 1763-6. PubMed Abstract

15. F Gething PW, Smith DL, Patil AP, et al:: Climate change and the global malaria recession. Nature. 2010; 465(7296): 342-5. PubMed Abstract | Publisher Full Text | Free Full Text | F1000 Recommendation

16. Danis K, Lenglet A, Tseroni M, et al:: Malaria in Greece: historical and current reflections on a re-emerging vector borne disease. Travel Med Infect Dis. 2013; 11(1): 8-14.

PubMed Abstract | Publisher Full Text

17. Tanser FC, Sharp B, le Sueur D: Potential effect of climate change on malaria transmission in Africa. Lancet. 2003; 362(9398): 1792-8. PubMed Abstract | Publisher Full Text

18. Caminade $\mathrm{C}$, Kovats $\mathrm{S}$, Rocklov J, et al:: Impact of climate change on global malaria distribution. Proc Natl Acad Sci U S A. 2014; 111(9): 3286-91. PubMed Abstract | Publisher Full Text | Free Full Text

19. Bhattacharya S, Sharma C, Dhiman RC, et al.: Climate change and malaria in India. Current Science. 2006; 90(3): 369-375 Reference Source

20. Peterson AT: Shifting suitability for malaria vectors across Africa with warming climates. BMC Infect Dis. 2009; 9: 59 . PubMed Abstract | Publisher Full Text | Free Full Text

21. Mordecai EA, Paaijmans KP, Johnson LR, et al:: Optimal temperature for malaria transmission is dramatically lower than previously predicted. Ecol Lett. 2013; 16(1): 22-30. PubMed Abstract | Publisher Full Text

22. F Murdock CC, Sternberg ED, Thomas MB: Malaria transmission potential could be reduced with current and future climate change. Sci Rep. 2016; 6 27771.

PubMed Abstract | Publisher Full Text | Free Full Text | F1000 Recommendation
23. Ryan SJ, McNally A, Johnson LR, et al.: Mapping physiological suitability limits for malaria in Africa under climate change. Vector Borne Zoonotic Dis. 2015; 15(12): 718-25.

PubMed Abstract | Publisher Full Text | Free Full Text

24. Hochachka PW, Somero GN: Biochemical Adaptation: Mechanism and Process in Physiological Evolution. 2002; Oxford University Press, Oxford, UK Reference Source

25. Hazel JR: Thermal adaptation in biological membranes: is homeoviscous adaptation the explanation? Annu Rev Physiol. 1995; 57: 19-42. PubMed Abstract | Publisher Full Text

26. Pörtner HO: Climate change and temperature-dependent biogeography: oxygen limitation of thermal tolerance in animals. Naturwissenschaften. 2001; 88(4): 137-46.

PubMed Abstract | Publisher Full Text

27. Huey RB, Stevenson RD: Integrating thermal physiology and ecology of ectotherms: a discussion of approaches. Am Zool. 1979; 19(1): 357-66. Publisher Full Text

28. Ronce O, Kirkpatrick M: When sources become sinks: migrational meltdown in heterogeneous habitats. Evolution. 2001; 55(8): 1520-31. PubMed Abstract | Publisher Full Text

29. Bennett AF, Lenski RE, Mittler JE: Evolutionary adaptation to temperature. I. fitness responses of Escherichia coli to changes in its thermal environment. Evolution. 1992; 46(1): 16-30. Publisher Full Text

30. Huey RB, Hertz PE: Is a jack-of-all-temperatures a master of none? Evolution. 1984; 38(2): 441-444. Publisher Full Text

31. Huey RB, Hertz PE, Sinervo B: Behavioral drive versus behavioral inertia in evolution: a null model approach. Am Nat. 2003; 161(3): 357-66. PubMed Abstract | Publisher Full Text

32. Parmesan $\mathrm{C}$ : Ecological and evolutionary responses to recent climate change. Annu Rev Ecol Evol Syst. 2006; 37: 637-69. Publisher Full Text

33. Deutsch CA, Tewksbury JJ, Huey RB, et al.: Impacts of climate warming on terrestrial ectotherms across latitude. Proc Natl Acad Sci U S A. 2008; 105(18) 6668-72.

PubMed Abstract | Publisher Full Text | Free Full Text

34. F Lafferty KD: The ecology of climate change and infectious diseases. Ecology. 2009; 90(4): 888-900.

PubMed Abstract | Publisher Full Text | F1000 Recommendation

35. Rigby MC, Hechinger RF, Stevens L: Why should parasite resistance be costly? Trends Parasitol. 2002; 18(3): 116-20. PubMed Abstract | Publisher Full Text

36. Ben-Horin T, Lenihan HS, Lafferty KD: Variable intertidal temperature explains why disease endangers black abalone. Ecology. 2013; 94(1): 161-8. PubMed Abstract | Publisher Full Text

37. Martin LB, Hopkins WA, Mydlarz LD, et al.: The effects of anthropogenic global changes on immune functions and disease resistance. Ann NY Acad Sci. 2010; 1195: 129-48.

PubMed Abstract | Publisher Full Text

38. Condeso TE, Meentemeyer RK: Effects of landscape heterogeneity on the emerging forest disease sudden oak death. J Ecol. 2007; 95(2): 364-75. Publisher Full Text

39. F Foxman EF, Storer JA, Fitzgerald ME, et al.: Temperature-dependent innate defense against the common cold virus limits viral replication at warm temperature in mouse airway cells. Proc Natl Acad Sci U S A. 2015; 112(3): 827-32. PubMed Abstract | Publisher Full Text | Free Full Text | F1000 Recommendation

40. Dobson A: Climate variability, global change, immunity, and the dynamics of infectious diseases. Ecology. 2009; 90(4): 920-7. PubMed Abstract | Publisher Full Text

41. Pascual M, Bouma MJ: Do rising temperatures matter? Ecology. 2009; 90(4): 906-12.

PubMed Abstract | Publisher Full Text

42. Torchin ME, Lafferty KD, Dobson AP, et al.: Introduced species and their missing parasites. Nature. 2003; 421(6923): 628-30.

PubMed Abstract | Publisher Full Text

43. Choi KM, Christakos G, Wilson ML: El Niño effects on influenza mortality risks in the state of California. Public Health. 2006; 120(6): 505-16. PubMed Abstract | Publisher Full Text

44. Laaksonen S, Pusenius J, Kumpula J, et al: Climate change promotes the emergence of serious disease outbreaks of filarioid nematodes. Ecohealth. 2010; 7(1): 7-13. PubMed Abstract | Publisher Full Text | Free Full Text

45. F Molnár PK, Kutz SJ, Hoar BM, et al:: Metabolic approaches to understanding climate change impacts on seasonal host-macroparasite dynamics. Ecol Lett. 2013; 16(1): 9-21.

PubMed Abstract | Publisher Full Text | F1000 Recommendation 
46. $\mathrm{F}$ Johnson PT, Chase JM, Dosch KL, et al:: Aquatic eutrophication promotes pathogenic infection in amphibians. Proc Natl Acad Sci U S A. 2007; 104(40): pathogen $15781-6$.

PubMed Abstract | Publisher Full Text | Free Full Text | F1000 Recommendation

47. F Paull SH, Johnson PT: Experimental warming drives a seasonal shift in the timing of host-parasite dynamics with consequences for disease risk. Ecol Lett. 2014; 17(4): 445-53.

PubMed Abstract | Publisher Full Text | F1000 Recommendation

48. Cairns MA, Ebersole JL, Baker JP, et al:: Influence of summer stream temperatures on black spot infestation of juvenile coho salmon in the Oregon coast range. Trans Am Fish Soc. 2005; 134(6): 1471-9.

Publisher Full Text

49. Koprivnikar J, Poulin R: Interspecific and intraspecific variation in cercariae release. J Parasitol. 2009; 95(1): 14-9. PubMed Abstract | Publisher Full Tex

50. Dawson RD, Hillen KK, Whitworth TL: Effects of experimental variation in temperature on larval densities of parasitic Protocalliphora (Diptera: Calliphoridae) in nests of tree swallows (Passeriformes: Hirundinidae). Environ Entomol. 2005; 34(3): 563-8. Publisher Full Text

51. $\mathrm{F}$ Paaijmans $\mathrm{KP}$, Blanford $\mathrm{S}$, Chan $\mathrm{BH}$, et al:: Warmer temperatures reduce the vectorial capacity of malaria mosquitoes. Biol Lett. 2012; 8(3): 465-8. PubMed Abstract | Publisher Full Text | Free Full Text | F1000 Recommendation

52. Casimiro E, Calheiros J, Santos FD, et al.: National assessment of human health effects of climate change in Portugal: approach and key findings. Environ Health Perspect. 2006; 114(12): 1950-6. PubMed Abstract | Publisher Full Text | Free Full Text

53. Casman E, Fischhoff B, Small M, et al.: Climate change and cryptosporidiosis: a qualitative analysis. Climatic Change. 2001; 50(1): 219-49. Publisher Full Text

54. Verant ML, Boyles JG, Waldrep W Jr, et al.: Temperature-dependent growth of Geomyces destructans, the fungus that causes bat white-nose syndrome. PLoS One. 2012; 7(9): e46280.

PubMed Abstract | Publisher Full Text | Free Full Text

55. Kilpatrick AM, Briggs CJ, Daszak P: The ecology and impact of chytridiomycosis: an emerging disease of amphibians. Trends Ecol Evol (Amst). 2010; 25(2): 109-18.

PubMed Abstract | Publisher Full Text

56. Rodder D, Kielgast J, Lotters S: Future potential distribution of the emerging amphibian chytrid fungus under anthropogenic climate change. Dis Aquat Organ. 2010; 92(2-3): 201-7.

PubMed Abstract | Publisher Full Text

57. Bally M, Garrabou J: Thermodependent bacterial pathogens and mass mortalities in temperate benthic communities: A new case of emerging disease linked to climate change. Global Change Biol. 2007; 13(10): 2078-88. Publisher Full Text

58. Bruno JF, Selig ER, Casey KS, et al.: Thermal stress and coral cover as drivers of coral disease outbreaks. PLOS Biol. 2007; 5(6): e124. PubMed Abstract | Publisher Full Text | Free Full Text

59. Bates AE, Hilton BJ, Harley CD: Effects of temperature, season and locality on wasting disease in the keystone predatory sea star Pisaster ochraceus. Dis Aquat Organ. 2009; 86(3): 245-51. PubMed Abstract | Publisher Full Tex

60. Eisenlord ME, Groner ML, Yoshioka RM, et al:: Ochre star mortality during the 2014 wasting disease epizootic: role of population size structure and temperature. Philos Trans R Soc Lond B Biol Sci. 2016; 371(1689): pii: 20150212. PubMed Abstract | Publisher Full Text | Free Full Text

61. Lafferty KD, Kuris AM: Mass mortality of abalone Haliotis cracherodii or the California Channel Islands: Tests of epidemiological hypothesis. Mar Ecol Prog Ser. 1993; 96: 239-48. Publisher Full Text

62. Vilchis LI, Tegner MJ, Moore JD, et al.: Ocean warming effects on growth, reproduction, and survivorship of southern california abalone. Ecological Applications. 2005; 15(2): 469-80.

Publisher Full Text

63. Lafferty KD, Holt RD: How should environmental stress affect the population dynamics of disease? Ecol Lett. 2003; 6(7): 654-64.

Publisher Full Text

64. Lafferty KD: Fishing for lobsters indirectly increases epidemics in sea urchins. Ecological Applications. 2004; 14(5): 1566-73.

Publisher Full Tex
65. Ward JR, Lafferty KD: The elusive baseline of marine disease: are diseases in ocean ecosystems increasing? PLOS Biol. 2004; 2(4): E120.

PubMed Abstract | Publisher Full Text | Free Full Text

66. Myers RA, Worm B: Rapid worldwide depletion of predatory fish communities. Nature. 2003; 423(6937): 280-3.

PubMed Abstract | Publisher Full Text

67. Béguin A, Hales S, Rocklöv J, et al.: The opposing effects of climate change and socio-economic development on the global distribution of malaria. Global Environmental Change. 2011; 21(4): 1209-14. Publisher Full Text

68. Bonds $\mathrm{MH}$, Keenan $\mathrm{DC}$, Rohani $\mathrm{P}$, et al:: Poverty trap formed by the ecology of infectious diseases. Proc Biol Sci. 2010; 277(1685): 1185-92. PubMed Abstract | Publisher Full Text | Free Full Text

69. Hay SI, Guerra CA, Gething PW, et al.: A world malaria map: Plasmodium falciparum endemicity in 2007. PLOS Med. 2009; 6(3): e1000048. PubMed Abstract | Publisher Full Text | Free Full Text

70. Wood CL, Lafferty KD, DeLeo G, et al:: Does biodiversity protect humans against infectious disease? Ecology. 2014; 95(4): 817-32. PubMed Abstract | Publisher Full Text

71. F Wesolowski A, Qureshi T, Boni MF, et al:: Impact of human mobility on the emergence of dengue epidemics in Pakistan. Proc Natl Acad Sci U S A. 2015. 112(38): 11887-92.

PubMed Abstract | Publisher Full Text | Free Full Text | F1000 Recommendation

72. Gilles J: In Zika Epidemic, a Warning on Climate Change. In New York Times. 2016: New York. Reference Source

73. Patz JA, Campbell-Lendrum D, Holloway T, et al:: Impact of regional climate change on human health. Nature. 2005; 438(7066): 310-7. PubMed Abstract | Publisher Full Text

74. Diaz HF, McCabe GJ: A possible connection between the $\mathbf{1 8 7 8}$ yellow fever epidemic in the southern United States and the 1877-78 El Niño episode. Bull Amer Meteor Soc. 1999; 80(1): 21-7.

Publisher Full Text

75. F Paz S, Semenza JC: El Niño and climate change--contributing factors in the dispersal of Zika virus in the Americas? Lancet. 2016; 387(10020): 745. PubMed Abstract | Publisher Full Text | F1000 Recommendation

76. F Musso D, Nilles EJ, Cao-Lormeau VM: Rapid spread of emerging Zika virus in the Pacific area. Clin Microbiol Infect. 2014; 20(10): 0595-6. PubMed Abstract | Publisher Full Text | F1000 Recommendation

77. F Bartel RA, Oberhauser KS, De Roode JC, et al:: Monarch butterfly migration and parasite transmission in eastern North America. Ecology. 2011; 92(2): 342-51.

PubMed Abstract | Publisher Full Text | F1000 Recommendation

78. Afrane YA, Zhou G, Lawson BW, et al.: Effects of microclimatic changes caused by deforestation on the survivorship and reproductive fitness of Anopheles gambiae in western Kenya highlands. Am J Trop Med Hyg. 2006; 74(5): 772-8. PubMed Abstract

79. Møller AP, Merino S, Soler JJ, et al:: Assessing the effects of climate on host-parasite interactions: a comparative study of European birds and their parasites. PLoS One. 2013; 8(12): e82886. PubMed Abstract | Publisher Full Text | Free Full Text

80. Hudson PJ, Cattadori IM, Boag B, et al:: Climate disruption and parasite-host dynamics: patterns and processes associated with warming and the frequency of extreme climatic events. $J$ Helminthol. 2006; 80(2): 175-82. PubMed Abstract | Publisher Full Text

81. Karvonen A, Rintamaki $\mathrm{P}$, Jokela J, et al.: Increasing water temperature and disease risks in aquatic systems: climate change increases the risk of some but not all, diseases. Int J Parasitol. 2010; 40(13): 1483-8. PubMed Abstract | Publisher Full Text

82. Lafferty KD: Calling for an ecological approach to studying climate change and infectious diseases. Ecology. 2009; 90(4): 932-3. PubMed Abstract | Publisher Full Tex

83. Parham PE, Waldock J, Christophides GK, et al.: Climate, environmental and socio-economic change: weighing up the balance in vector-borne disease transmission. Philos Trans R Soc Lond B Biol Sci. 2015; 370(1665): pii: 20130551. PubMed Abstract | Publisher Full Text | Free Full Text

84. Rohr JR, Dobson AP, Johnson PT, et al:: Frontiers in climate change-disease research. Trends Ecol Evol. 2011; 26(6): 270-7. PubMed Abstract | Publisher Full Text | Free Full Text 


\section{Open Peer Review}

\section{Current Peer Review Status:}

\section{Editorial Note on the Review Process}

Faculty Reviews are review articles written by the prestigious Members of Faculty Opinions. The articles are commissioned and peer reviewed before publication to ensure that the final, published version is comprehensive and accessible. The reviewers who approved the final version are listed with their names and affiliations.

\section{The reviewers who approved this article are:}

\section{Version 1}

\section{Maria Diuk-Wasser}

Columbia University, New York, NY, USA

Competing Interests: No competing interests were disclosed.

\section{Camille Parmesan}

Plymouth University, Plymouth, UK

Competing Interests: No competing interests were disclosed.

The benefits of publishing with F1000Research:

- Your article is published within days, with no editorial bias

- You can publish traditional articles, null/negative results, case reports, data notes and more

- The peer review process is transparent and collaborative

- Your article is indexed in PubMed after passing peer review

- Dedicated customer support at every stage

For pre-submission enquiries, contact research@f1000.com 